\title{
Article \\ Highly Sensitive Amperometric Sensor Based on Laccase-Mimicking Metal-Based Hybrid Nanozymes for Adrenaline Analysis in Pharmaceuticals
}

\author{
Olha Demkiv ${ }^{1,2}$, Nataliya Stasyuk $1,3, * \mathbb{D}$, Galina Gayda ${ }^{1}\left(\mathbb{D}\right.$ and Mykhailo Gonchar ${ }^{1,3, *}$ \\ 1 Institute of Cell Biology, National Academy of Sciences of Ukraine, 79005 Lviv, Ukraine; \\ demkivo@nas.gov.ua (O.D.); galina.gayda@gmail.com (G.G.) \\ 2 Faculty of Veterinary Hygiene, Ecology and Law, Stepan Gzhytskyi National University of Veterinary \\ Medicine and Biotechnologies, 79000 Lviv, Ukraine \\ 3 Department of Biology and Chemistry, Drohobych Ivan Franko State Pedagogical University, \\ 82100 Drohobych, Ukraine \\ * Correspondence: stasuk_natalia@ukr.net (N.S.); mykhailo1952@gmail.com (M.G.); \\ Tel.: +380-226-2144 (N.S. \& M.G.)
}

Citation: Demkiv, O.; Stasyuk, N.; Gayda, G.; Gonchar, M. Highly Sensitive Amperometric Sensor Based on Laccase-Mimicking Metal-Based Hybrid Nanozymes for Adrenaline Analysis in Pharmaceuticals. Catalysts 2021, 11, 1510. https://doi.org/ 10.3390/catal11121510

Academic Editor: Oliver Strube

Received: 19 November 2021

Accepted: 9 December 2021

Published: 11 December 2021

Publisher's Note: MDPI stays neutral with regard to jurisdictional claims in published maps and institutional affiliations.

Copyright: (c) 2021 by the authors. Licensee MDPI, Basel, Switzerland. This article is an open access article distributed under the terms and conditions of the Creative Commons Attribution (CC BY) license (https:// creativecommons.org/licenses/by/ $4.0 /)$.

\begin{abstract}
Nanozymes are nanomaterials which exhibit artificial enzymatic activities and are considered as alternatives to natural enzymes. They are characterized by good catalytic activity and high stability, as well as ease and low cost of preparation. In this study, the mimetics of laccase or "nanolaccases" (NLacs) were synthesized by a simple method of chemical reduction of transition metal salts. The NLacs were tested for their catalytic activity in solution and on the electrode surface. The most effective NLacs, namely $\mathrm{nAuCePt}$ and $\mathrm{nPtFe}$, were found to possess excellent laccase-like activities capable of oxidizing the endocrine hormone adrenaline (AD). These NLacs were characterized in detail and used for the development of amperometric sensors for AD determination. The amperometric sensors containing the best NLacs, as well as a natural fungal laccase, were constructed. The most effective nAuCePt-containing sensor had good specificity in relation to AD and improved analytical characteristics. It possessed a 384-fold higher sensitivity than adrenaline $\left(230,137 \mathrm{~A} \cdot \mathrm{M}^{-1} \cdot \mathrm{m}^{-2}\right)$, a 64-fold lower limit of detection $(0.025 \mu \mathrm{M})$, and a broader linear range $(0.085-45 \mu \mathrm{M})$ in comparison with the sensor based on natural laccase. The constructed nAuCePt-containing sensor was successfully used for AD analysis in pharmaceutical formulation.
\end{abstract}

Keywords: laccase-lake nanozyme; adrenaline assay; laccase; amperometric sensor; pharmaceuticals

\section{Introduction}

The detection of biologically active toxic pharmaceutical compounds and their metabolites in surface waters cause great concern for humanity [1,2]. Several chemicals have already been found in raw urban wastewaters at concentrations up to $\mu \mathrm{g} \cdot \mathrm{L}^{-1}$, which are dangerous for health [3].

Pharmaceutical manufacturing has become a significant source of harmful chemicals as pollutants of the environment. Even after treatment facilities, the concentrations of toxic compounds in the wastewaters of these factories may be 10-1000 times higher than safe values. In addition, households and hospitals make a significant contribution to the excretion of pharmaceuticals into urban wastewaters [4].

Among the chemicals detected in terrestrial and aquatic environments, some antiinflammatories and analgesics, catecholamines and psychiatric drugs are the most dangerous for humans and wildlife [5]. As the influence of these contaminants in the environment is clearly recognized, early detection and quantification of the mentioned pharmaceuticals is necessary, not only for controlling the quality of water, especially drinking water, but also for the diagnosis and monitoring of various health conditions $[4,6]$. 
The catecholamines-noradrenaline, adrenaline (also called, epinephrine) and dopamine-are key neurotransmitters in the sympathetic nervous system, as they stimulate adrenergic receptors in a wide variety of cells [7]. High concentrations of adrenaline (AD) correlate well with glycogenolysis in the liver, hypoglycemia, myocardial infarction, lipolysis in the adipose tissue, and the heart contraction rate [8]. AD is an important biomarker for Parkinson's disease [9] and other malignances [10]. Thus, AD and other catecholamines are secreted in excessive amounts by pheochromocytomas (tumors of the adrenal glands).

A variety of analytical techniques for the determination of $\mathrm{AD}$ has been reported-among them, liquid chromatography [11], spectrophotometry [12], capillary electrophoresis [13], fluorometry [14], high-pressure liquid chromatography, and circular dichroism [15] — which are characterized by low selectivity, high costs, and time consumption. Within the last few years, electrochemical methods for the analysis of pharmaceuticals, especially catecholamines, have become very popular. However, only a limited number of papers have reported the electrochemical detection of $\mathrm{AD}$. Electrochemical approaches for $\mathrm{AD}$ analysis are preferable to laborious instrumental methods due to the simplicity of procedures and instrumentation, fast response, sensitivity, and low cost [16].

To construct amperometric biosensors, laccase preparations and different nanomaterials were used [17-28]. The proposed laccase-based sensors have been utilized to monitor the level of $\mathrm{AD}$ in pharmaceuticals, even though the practical application of such biosensors is often limited due to the impact of environmental compartments on the enzyme in the recognition layer $[17,18]$.

Artificial enzymes with pseudo-laccase activity, especially nano-size laccase-like nanozymes (NZs) or "nanolaccases (NLacs)", have preferential properties compared to natural enzymes. Thus, the search for new effective NLacs, which are promising for construction of electrochemical sensors, appears to be an urgent task [19-28].

In the current work, we report the synthesis of NLacs, their characterization, and their application in the development of amperometric sensors for the direct measurement of AD. The most effective sensors contain metal-hybrid NZs on the surfaces of graphite electrodes. The proposed sensor was successfully tested for AD determination in a pharmaceutical product.

\section{Results and Discussion}

\subsection{Synthesis and Characterization of the NLacs}

A number of metal-based composite materials were synthesized using the method of chemical reduction. The synthesized NZs were screened for their ability to oxidize ABTS in the solution (Table 1). A natural laccase preparation from Trametes gibbosa 1525 was used for comparison. It was shown that several tested NZs, especially nAuCePt and $\mathrm{nFePt}$, possessed significant laccase-like activities. The most catalytically active NZs in the solution were characterized by scanning electron microscopy (SEM).

Table 1. Laccase-like activities of the synthesized NZs in solution.

\begin{tabular}{|c|c|c|}
\hline No & $\mathrm{NZ}$ & Specific Activity, U.mg ${ }^{-1}$ \\
\hline 1 & $\mathrm{nAuCePt}$ & $2.90 \pm 0.25$ \\
\hline 2 & $\mathrm{nAuCe}$ & $0.85 \pm 0.15$ \\
\hline 3 & $\mathrm{nPtFe}$ & $1.40 \pm 0.10$ \\
\hline 4 & $\mathrm{nFePtPd}$ & $0.70 \pm 0.05$ \\
\hline 5 & nAuPtPd & $0.30 \pm 0.02$ \\
\hline 6 & nCoPtPd & $0.40 \pm 0.02$ \\
\hline 7 & Laccase & $12.0 \pm 0.11$ \\
\hline
\end{tabular}

Figure 1 presents the overall morphology of the formed particles. According to SEM images, nAuCePt have the shape of prisms, with sizes varying from 20 to $100 \mu \mathrm{m}$ (Figure $1 \mathrm{a}-\mathrm{c}$ ). The obtained $\mathrm{nPtFe}$ have the shape of cubes, with sizes varying from 4 to 
$10 \mu \mathrm{m}$ (Figure $1 \mathrm{~d}-\mathrm{f})$. It was shown that the characteristic peaks on the XRM images corresponded to $\mathrm{Ce}^{0}, \mathrm{Pt}^{0}, \mathrm{Au}^{0}$, and $\mathrm{Fe}^{0}$ (Figure 1c,f). It was demonstrated (the data are not shown) that the sizes of all the studied compounds do not satisfy the nanoscale criterion of being less than $100 \mathrm{~nm}$ in all three dimensions. In some cases, they are nanoscale only in one dimension (plate), while in the others, they exceed the criterion. This is most likely due to the aggregation of the initially formed NZs. To take this factor into account, we classify NZs as materials whose nanoscale is confirmed by physical methods for at least one dimension.



(a)

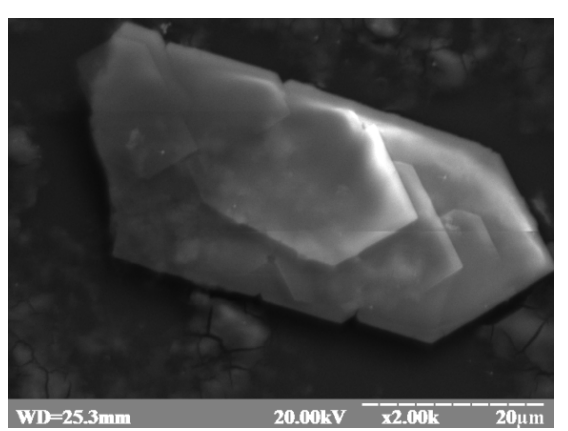

(b)

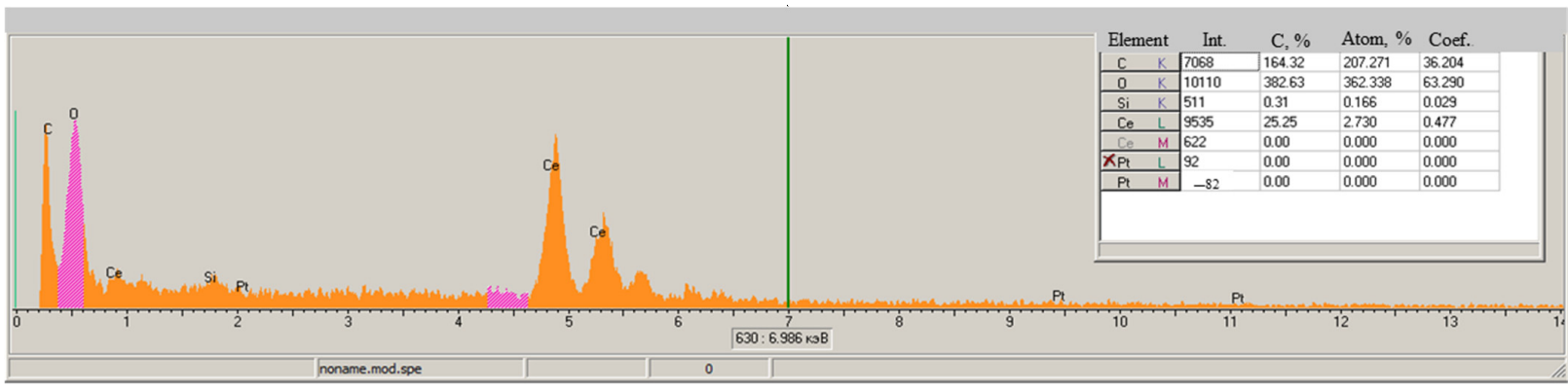

(c)

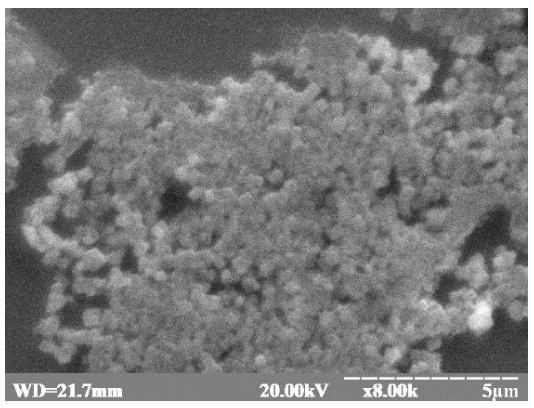

$(\mathbf{d})$

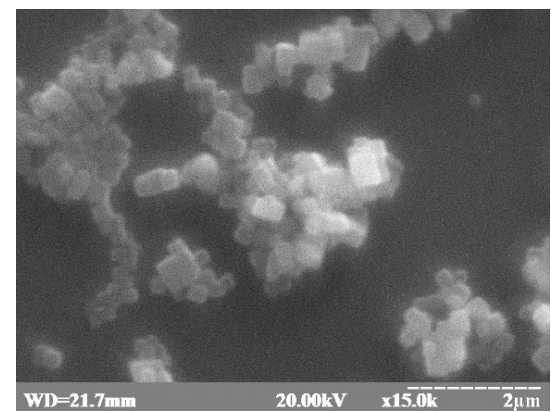

(e)

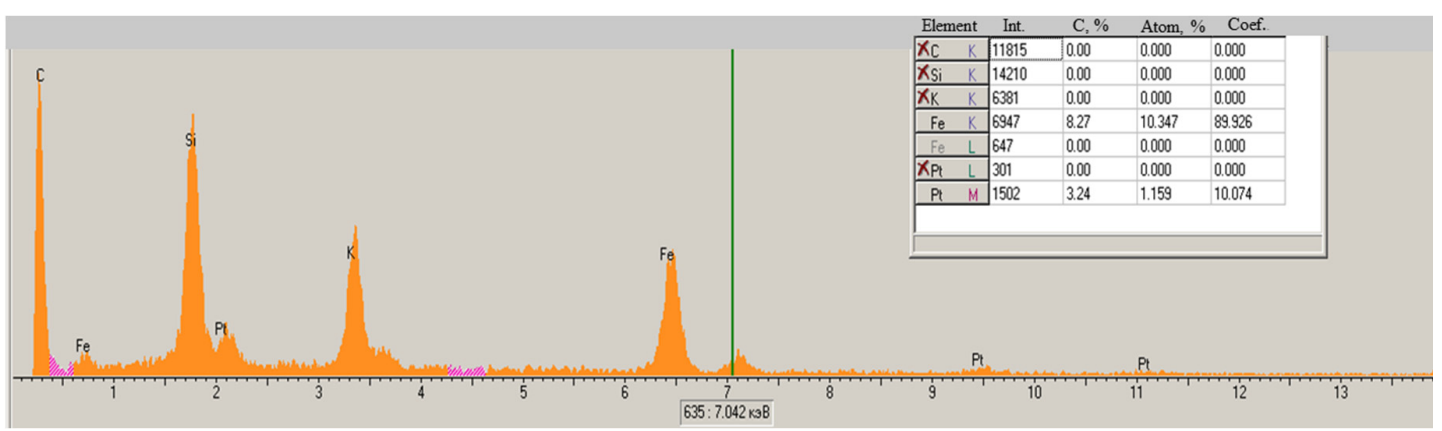

(f)

Figure 1. Characteristics of the $\mathrm{nAuCePt}(\mathbf{a}-\mathbf{c})$ and $\mathrm{nPtFe}(\mathbf{d}-\mathbf{f}) \mathrm{NZs}$ : SEM images $(\mathbf{a}, \mathbf{b}, \mathbf{d}, \mathbf{e})$; $\mathrm{X}$-ray spectral microanalysis $(\mathbf{c}, \mathbf{f})$. 


\subsection{The Development and Characterization of the NZ-Modified Electrodes}

Here, we proposed a new sensor for AD determination based on metal-hybrid NLacs immobilized on a graphite surface of the electrode (further marked as NZ/GE). Figure 2 shows a scheme of the chemical processes between $\mathrm{AD}$ (also called epinephrine) and NLacs. The synthesized NLacs (for example, $\mathrm{nAuCePt}$ ) catalyze the oxidation of AD to adrenochrome. The last compound is reduced on the surface of GE under the potential of $50 \mathrm{mV}$. The resulting cathodic currents correlate directly with the concentration of AD in the sample solution.

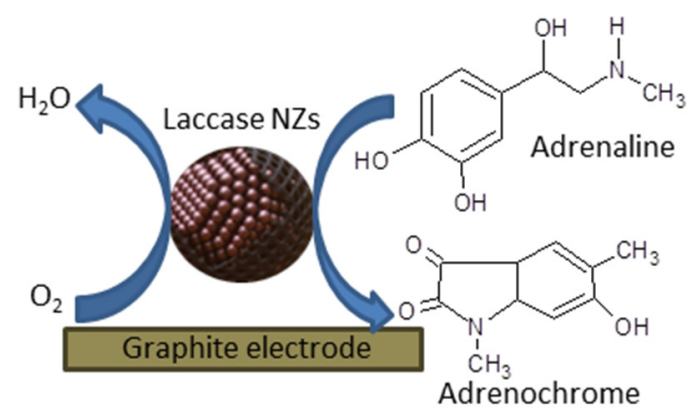

Figure 2. The principal scheme of the AD determination.

The nanozymes nAuCePt and nPtFe were deposited on the top of a GE rod electrode (marked as $\mathrm{nAuCePt} / \mathrm{GE}$ and $\mathrm{nFePt} / \mathrm{GE}$, respectively), as described in Section 3.6, and their electro-catalytic activities toward AD oxidation were compared with laccase/GE. Figures 3-5 demonstrate the electrochemical characteristics of the developed sensors as current responses upon $\mathrm{AD}$ addition, namely cyclic voltamperograms $(\mathrm{CV})$ with a scan rate of $50 \mathrm{mV} \cdot \mathrm{s}^{-1}$, chronoamperograms, and calibration curves under optimal working potentials, which were determined from the CV.

Following the chronoamperograms for the constructed amperometric sensors (Figures $3 b, 4 b$ and $5 b$ ), we plotted the calibration curves for AD determination as illustrated in Figures $3 c, 4 c$ and $5 c$. The linear ranges for $\mathrm{AD}$ determination and sensitivities were calculated for all obtained modified electrodes (Figures $3 \mathrm{~d}, 4 \mathrm{~d}$ and $5 \mathrm{~d}$ ).

The $\mathrm{CV}$ for the $\mathrm{nAuCePt} / \mathrm{GE}$ (Figure 3a) demonstrated that the cathodic reduction peak, contributed by AD decomposition, arose at potentials of approximately $-50 \mathrm{mV}$ (vs. $\mathrm{Ag} / \mathrm{AgCl}$ ). The $\mathrm{CV}$ for the $\mathrm{nPtFe} / \mathrm{GE}$ (Figure $4 \mathrm{a}$ ) demonstrated that the anodic oxidation peak arose at the potential of approximately $+250 \mathrm{mV}$. The chronamperometric dependences and calibration graphs for AD determination are shown in Figures 3 and $4 \mathrm{~b}-\mathrm{d}$ respectively for both types of NZs. As a control measure, the unmodified GE was tested, and no signal was detected upon $\mathrm{AD}$ addition (the data not shown).

Figures $3 c, 4 c$ and $5 c$ present the maximal current responses on $A D$ at substrate saturation $\left(I_{\max }\right)$ and the apparent Michaelis-Menten constants $\left(\mathrm{K}_{\mathrm{M}}{ }^{\mathrm{app}}\right)$ to AD. nAuCePt/GE was shown to have the highest $I_{\max }$ (27-fold increase compared to that of laccase/GE) and the lowest $\mathrm{K}_{\mathrm{M}}$ app among the sensors reported here.

The analytical characteristics of the developed electrodes on AD in comparison with the known sensors are summarized in Table 2. As demonstrated in Table 2, for AD detection, not only laccase preparations but also various nanomaterials may be used [17-28] Some of the reported sensors exhibit excellent analytical properties, having low limits of detection ( $2 \mathrm{nM}$ [27] or $9 \mathrm{nM}$ [26]) and wide linear ranges (for example, from $0.7 \mu \mathrm{M}$ to $1200 \mu \mathrm{M}$ [22]). However, the main disadvantages of these sensors are insufficient sensitivity [20] and high working potentials $(+400 \mathrm{mV})$ [27]. The $\mathrm{nAuCePt} / \mathrm{GE}$ proposed by us was shown to possess the highest sensitivity to $\mathrm{AD}$ in comparison with the reported (bio)sensors, this value showing a 384-fold increase compared to that of laccase/GE (Table 2).

As a result of our study, we can conclude that nAuCePt and nAuPtPd possess excellent sensitivities and wide linear-ranges for $\mathrm{AD}$ detection and may, thus, be considered as promising mimetics of laccase in amperometric sensors. 


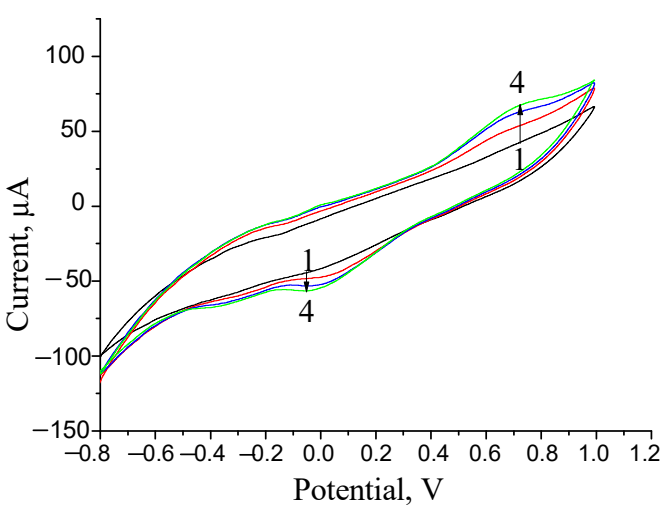

(a)



(c)

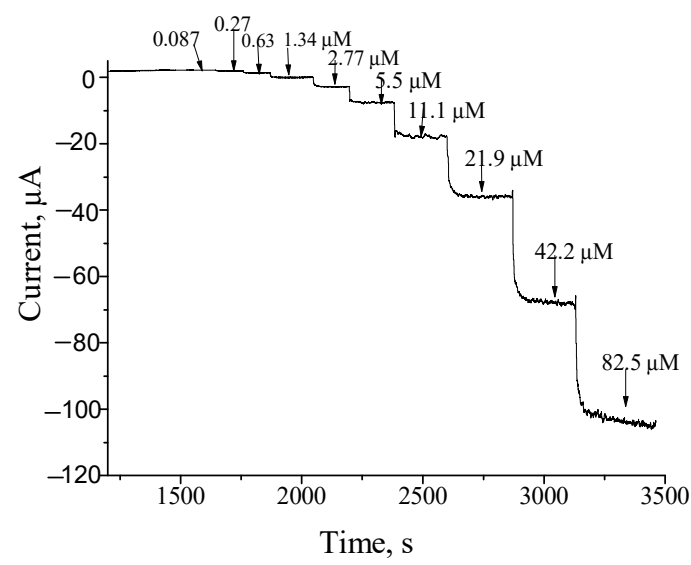

(b)

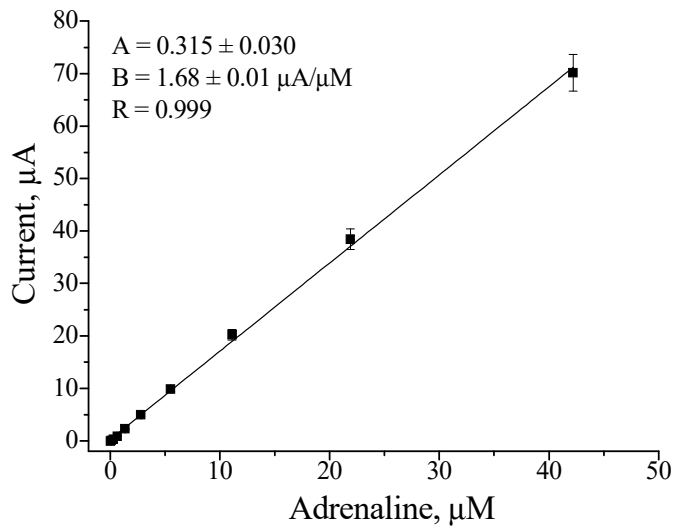

(d)

Figure 3. Characteristics of $\mathrm{nAuCePt} / \mathrm{GE}$ : CV as current responses upon AD addition up to $0 \mathrm{mM}(1, \mathrm{black}$ line), $4 \mu \mathrm{M}$ (2, red line), $8 \mu \mathrm{M}$ (3, blue line), and $16 \mathrm{mM}$ (4, green line) concentrations (a); chronamperometric response (b), dependence of amperometric signal on concentration of $\mathrm{AD}(\mathbf{c})$ and calibration graph (d) under working potential $-50 \mathrm{mV}$.

Table 2. Analytical characteristics of the developed laccase-like NZ/GE as chemosensors for adrenaline in comparison with the known sensors for AD assay.

\begin{tabular}{|c|c|c|c|c|c|c|}
\hline Sensing Element & $\begin{array}{l}\text { Potential, } \\
\text { mV }\end{array}$ & $\begin{array}{l}\text { Sensitivity, } \\
\mathrm{A} \cdot \mathbf{M}^{-1} \cdot \mathbf{m}^{-2}\end{array}$ & $K_{M}^{a p p}, \mathbf{m M}$ & $\begin{array}{c}\text { Linear } \\
\text { Range, } \mu \mathrm{M}\end{array}$ & $\begin{array}{c}\text { LOD, } \\
\mu \mathrm{M}\end{array}$ & Reference \\
\hline Laccase $/ \mathrm{PtNPs} / \mathrm{PtE}^{1}$ & +50 & 3570 & - & up to 55 & 0.4 & [17] \\
\hline Laccase/PPy-PVS ${ }^{2} / \mathrm{PtE}$ & -220 & $8000^{3}$ & $27 \times 10^{-6}$ & $\begin{array}{c}0.1-1.0 \\
1-10\end{array}$ & 0.01 & [18] \\
\hline AuNPs/PANi/GCE ${ }^{4}$ & - & - & - & $0.4-40$ & 0.08 & [19] \\
\hline $\mathrm{IrOx} / \mathrm{SPE}^{5}$ & - & 30 & - & $0.1-15$ & 0.03 & [20] \\
\hline $\begin{array}{c}\text { Graphite powder: laccase:Nujol: } \\
\text { Pt-BMI.PF6 }{ }^{6} / \mathrm{CPE}^{7}\end{array}$ & - & - & - & $0.1-213$ & 0.029 & [21] \\
\hline $\begin{array}{l}\text { Graphite powder-carbon } \\
\text { nanotube-EBNBH } \\
\\
\text { complex-paraffin/GCE }{ }^{9}\end{array}$ & +265 & - & - & $0.7-1200$ & 0.216 & [22] \\
\hline $\mathrm{MWCNT} / \mathrm{CFE}^{10}$ & -100 & 420 & - & up to 100 & 2 & [23] \\
\hline Os-(PVP) $10 /$ Nafion/GCE & - & 316 & 0.51 & $2-113$ & - & {$[24]$} \\
\hline MWCNT-CoTSPc/GCE 6 & - & 1860 & - & $3.0-15$ & 0.450 & [25] \\
\hline
\end{tabular}


Table 2. Cont.

\begin{tabular}{|c|c|c|c|c|c|c|}
\hline Sensing Element & $\begin{array}{l}\text { Potential, } \\
\mathrm{mV}\end{array}$ & $\begin{array}{r}\text { Sensitivity, } \\
\mathbf{A} \cdot \mathbf{M}^{-1} \cdot \mathbf{m}^{-2}\end{array}$ & $K_{M}^{a p p}, \mathbf{m M}$ & $\begin{array}{c}\text { Linear } \\
\text { Range, } \mu \mathrm{M}\end{array}$ & $\begin{array}{c}\text { LOD, } \\
\mu \mathrm{M}\end{array}$ & Reference \\
\hline MXene/GPE & +100 & - & - & $\begin{array}{l}0.02-10 \\
10-100\end{array}$ & 0.009 & [26] \\
\hline Aminated graphene/AgNPs/GCE & +400 & - & - & $0.916-184$ & 0.002 & [27] \\
\hline $\mathrm{Na}\left[\mathrm{RuL}_{2}\right] / \mathrm{GCE}$ & \multirow{3}{*}{+100} & \multirow{3}{*}{-} & - & $27-136$ & 35 & \multirow{3}{*}{ [28] } \\
\hline $\mathrm{SP} / \mathrm{Na}\left[\mathrm{RuL}_{2}\right] /$ cellulose acetate/CE & & & - & $27-272$ & 1.3 & \\
\hline $\mathrm{SP} / \mathrm{Na}\left[\mathrm{RuL}_{2}\right] / \mathrm{MWCNTs} / \mathrm{CE}$ & & & - & $54-272$ & 0.35 & \\
\hline $\mathrm{nAuCePt} / \mathrm{GE}$ & -50 & 230,137 & 0.13 & $0.085-45$ & 0.025 & \multirow{6}{*}{$\begin{array}{c}\text { Current } \\
\text { work }\end{array}$} \\
\hline nAuPtPd/GE & +250 & 10,137 & 0.11 & $0.530-32$ & 0.5 & \\
\hline $\mathrm{nPtFe} / \mathrm{GE}$ & +250 & 4900 & 0.73 & $0.530-120$ & 0.9 & \\
\hline $\mathrm{nFePtPd} / \mathrm{GE}$ & +250 & 3000 & 0.88 & $1.65-53$ & 0.9 & \\
\hline nCoPtPd/GE & +250 & 2950 & 0.66 & $1.65-61$ & 0.9 & \\
\hline Laccase/GE & +100 & 600 & 1.72 & $5-600$ & 1.6 & \\
\hline
\end{tabular}

${ }^{1} \mathrm{PtE}$ - platinum-rod electrode; ${ }^{2} \mathrm{PPy}-\mathrm{PVS}$ - polypyrrole-polyvinylsulphonate; ${ }^{3}$ calculated from the calibration graphs; ${ }^{4} \mathrm{AuNPs} / \mathrm{PANi} /$ GCE—Gold nanoparticles/polyaniline Langmuir-modified glassy-carbon; ${ }^{5}$ IrOx/SPE-iridium-oxide modified screen-printed electrode; ${ }^{6}$ Pt-BMI.PF6-PtNPs in 1-butyl-3-methylimidazolium hexafluorophosphate; ${ }^{7} \mathrm{CPE}$-carbon-paste electrode; ${ }^{8} \mathrm{EBNBH}-2,2-[1,2-$ ethanediylbis(nitriloethylidyne)]-bis-hydroquinone double-wall carbon-nanotube; ${ }^{9} \mathrm{GCE}$ - glassy-carbon electrode; ${ }^{10} \mathrm{MWCNT} / \mathrm{CFE}-$ carbon-film electrode (CFE) modified with multiwalled carbon-nanotubes (MWCNTs).

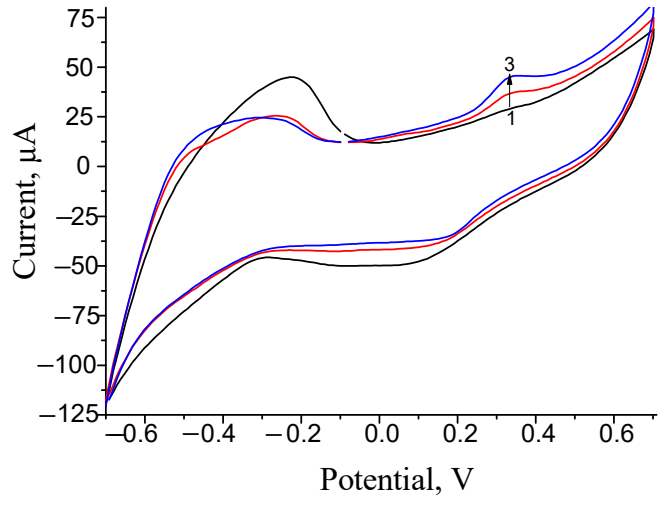

(a)

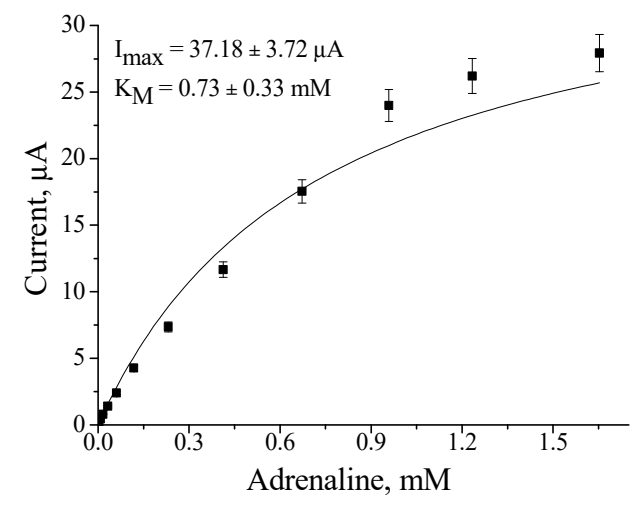

(c)

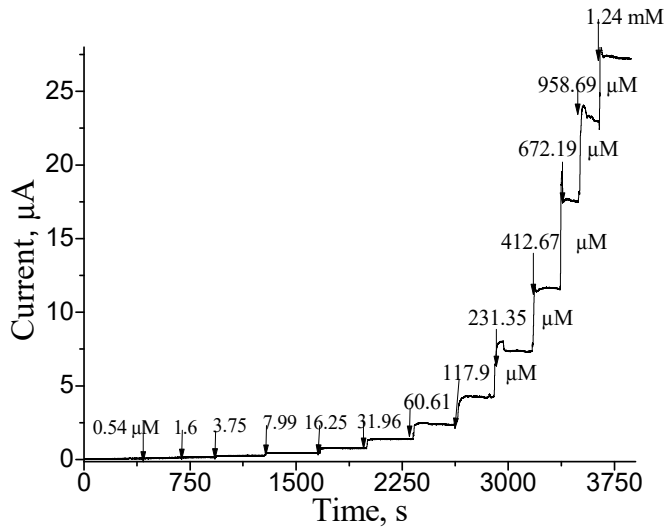

(b)

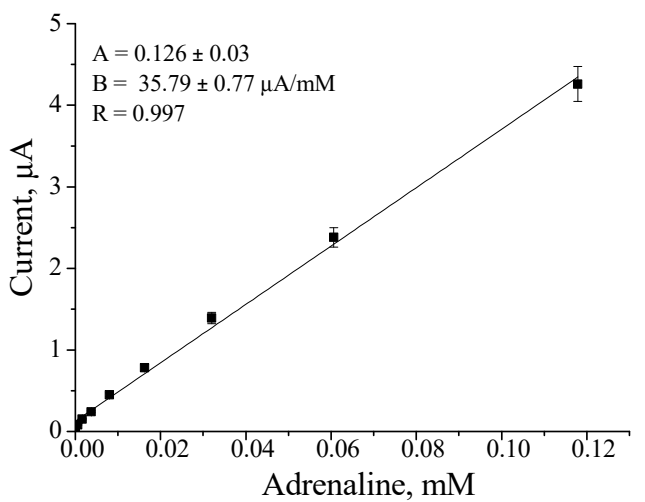

(d)

Figure 4. Characteristics of $\mathrm{nPtFe} / \mathrm{GE}: \mathrm{CV}$ as current responses upon $\mathrm{AD}$ addition up to $0 \mathrm{mM}(1$, black line), $4 \mu \mathrm{M}(2$, red line) and $8 \mu \mathrm{M}(3$, blue line), concentrations (a); chronamperometric response (b), dependence of amperometric signal on concentration of AD (c) and calibration graph (d) under working potential $+250 \mathrm{mV}$. 


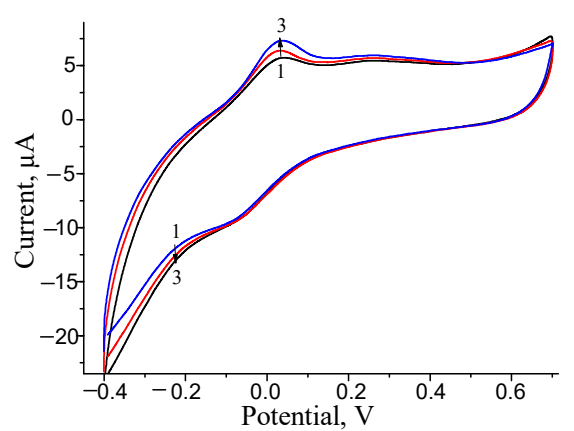

(a)

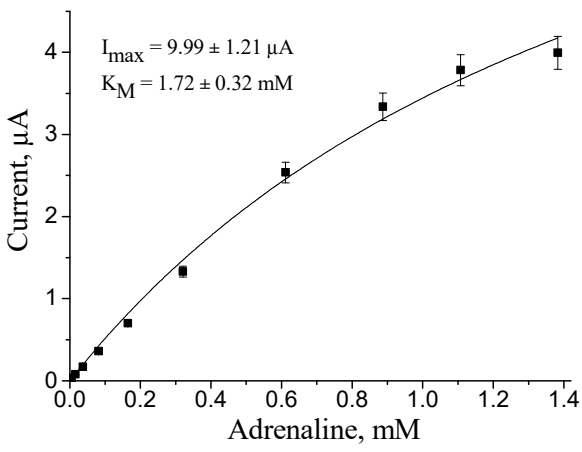

(c)

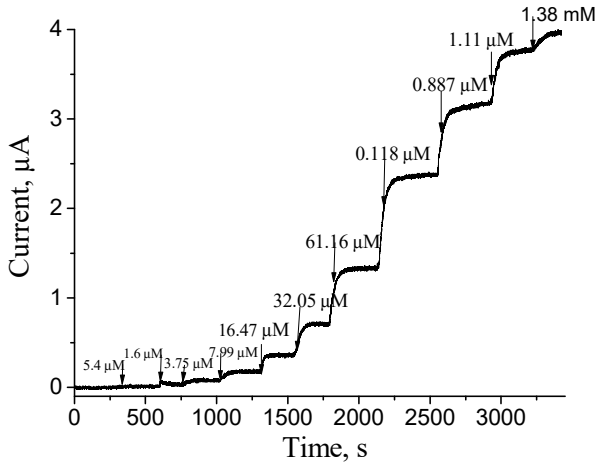

(b)

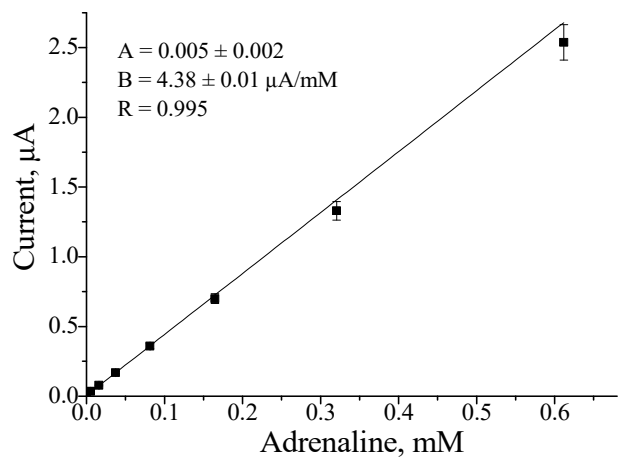

(d)

Figure 5. Characteristics of laccase/GE: $\mathrm{CV}$ as current responses upon AD addition up to $0 \mathrm{mM}(1$, black line), $4 \mu \mathrm{M}(2$, red line) and $8 \mu \mathrm{M}(3$, blue line) concentrations (a); chronamperometric response (b), dependence of amperometric signal on concentration of $\mathrm{AD}(\mathbf{c})$ and calibration graph (d) under working potential $+100 \mathrm{mV}$.

\subsection{Characterization of the Most Effective $n A u C e P t-B a s e d$ Electrode and Its Application}

In general, the specificity of a recognition element in relation to the target analyte is a valuable characteristic for its use in sensors. The results of the selectivity test for the constructed nAuCePt/GE are presented in Figure 6. The NZ-based electrode was shown to be highly specific to AD. In the case of adding structurally similar compounds as well as solutions of glucose and sodium chloride, the signals of the sensor are insignificant (less than $5 \%$ ). The latter compounds are often used as solubilizers in pharmaceuticals.

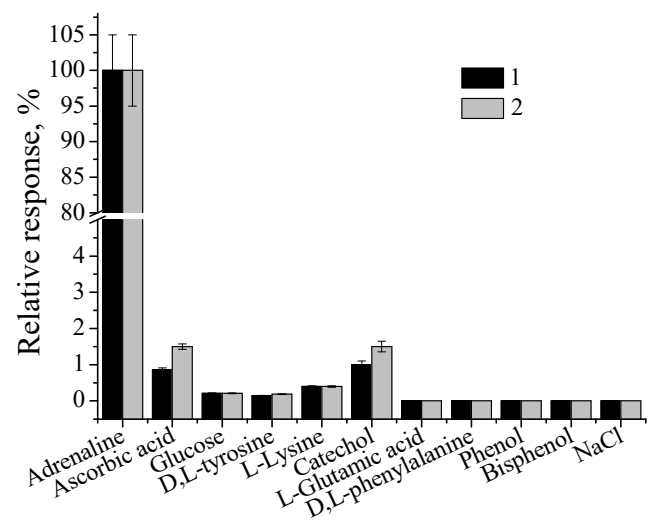

Figure 6. Selectivity for $\mathrm{nAuCePt} / \mathrm{GE}$. The test was performed with $2 \mathrm{mM}$ (1) and $4 \mathrm{mM}$ (2) solutions of different analytes under the working potential of $-50 \mathrm{mV}$. The amperometric signal on AD being the highest was chosen as $100 \%$.

To experience $\mathrm{nAuCePt} / \mathrm{GE}$ as an $\mathrm{AD}$-selective sensor for determination of $\mathrm{AD}$ concentration, a commercial pharmaceutical product was analyzed under optimal condi- 
tions. The tested sample in the ampoule was the solution for the injection of "Adrenaline (Epinephrine)". For the analysis of AD in the sample of the pharmaceutical, the method called the "Standard Addition Test" (SAT) was used for two dilutions (Figure 7). The principles of the graphical analytical method SAT, as well as the algorithm for the calculation of an analyte's concentration from the parameters of linear regression, were described earlier [29].

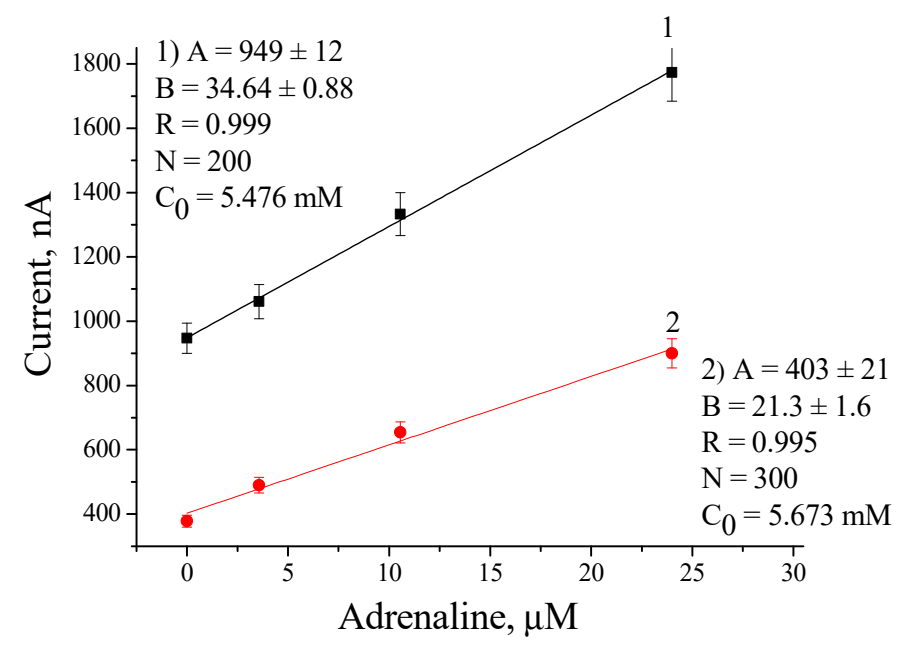

Figure 7. Determination of AD concentration in the sample of the pharmaceutical "Adrenaline (Epinephrine)" solution (for injection in the ampoule) using the nAuCePt-based chemosensor with the SAT method.

The values of $\mathrm{AD}$ concentration in the commercial sample, which were estimated using the developed sensor and declared by the manufacturer, are presented in Table 3. Both concentrations of AD correlate well (Table 3), with an error of less than $5 \%$.

Table 3. Results of AD estimation in pharmaceutical "Adrenaline".

\begin{tabular}{|c|c|c|c|c|c|}
\hline \multirow{3}{*}{ Commercial Sample } & \multicolumn{3}{|c|}{ Concentration of $\mathrm{AD}$} & \multirow{3}{*}{$\mathrm{CV}, \%$} & \multirow{3}{*}{ Producer } \\
\hline & \multicolumn{2}{|c|}{ Estimated } & \multirow{2}{*}{ Declared, \% } & & \\
\hline & $\mathbf{m M}$ & $\%$ & & & \\
\hline $\begin{array}{c}\text { Adrenaline (Epinephrine) } \\
\text { solution for injection, ampoule }\end{array}$ & $5.57 \pm 0.25$ & 0.185 & 0.180 & 2.7 & $\begin{array}{l}\text { Pharmaceutical factory } \\
\text { "Darnytsia", Kyiv, Ukraine }\end{array}$ \\
\hline
\end{tabular}

\section{Materials and Methods}

\subsection{Reagents}

Gold(III) chloride solution $\left(\mathrm{HAuCl}_{4}\right)$, Cerium(III) hydrocarbonate $\left(\mathrm{Ce}\left(\mathrm{HCO}_{3}\right)_{4}\right)$, chloroplatinic acid $\left(\mathrm{H}_{2} \mathrm{PtCl}_{6}\right)$, palladium chloride $\left(\mathrm{PdCl}_{3}\right)$, copper(II) sulfate $\left(\mathrm{CuSO}_{4}\right)$, iron(III) chloride $\left(\mathrm{FeCl}_{3} \cdot 4 \mathrm{H}_{2} \mathrm{O}\right)$, Cobalt(II) chloride hexahydrate $\left(\mathrm{CoCl}_{2} \cdot 6 \mathrm{H}_{2} \mathrm{O}\right)$, adrenaline, o-dianisidine, ascorbic acid, sodium borohydride $\left(\mathrm{NaBH}_{4}\right)$, catechol, glucose, $\mathrm{D}, \mathrm{L}$-tyrosine, L-Lysine, L-glutamic acid, D,L-phenylalanine, phenol, bisphenol, $\mathrm{NaCl}$, Nafion (5\% solution in 90\% ethanol), 2,2'-Azino-bis(3-ethylbenzthiazoline-6-sulfonic acid) (ABTS) and all other reagents and solvents used in this work were purchased from Sigma-Aldrich (Steinheim, Germany). All solutions were prepared using ultrapure water obtained with the Milli- $Q^{\circledR}$ IQ 7000 Water (Merck KGaA, Darmstadt, Germany).

\subsection{Isolation and Purification of Laccase}

Laccase was isolated from the fungus Trametes gibbosa 1525. The cells were cultivated at $28{ }^{\circ} \mathrm{C}$ in YPD medium supplemented with $1 \%$ sucrose and $0.05 \mathrm{mM} \mathrm{Cu}^{2+}$ for 5 days. To remove the mycelia, the fungal culture was passed through filter paper, and a cultural 
liquid was used for enzyme isolation. Laccase with activity of $\geq 10 \mathrm{U} \cdot \mathrm{mg}^{-1}$ was purified according to the described method [30].

The laccase activity was determined in kinetic mode spectrophotometrically at $420 \mathrm{~nm}$ (Shimadzu, Kyoto, Japan) as described earlier [30]. As a substrate, $0.5 \mathrm{mM}$ ABTS in $50 \mathrm{mM}$ sodium acetate buffer solution, with a $\mathrm{pH}$ of 4.5 , was used.

\subsection{Synthesis and Characterization of Laccase-like NZs}

The tri-metallic composites of nCoPtPd, nFePtPd, and nAuPtPd were obtained according to the protocol, which was proposed for nNiPtPd synthesis [31], using $\mathrm{NaBH}_{4}$ as a reducing agent.

To obtain $\mathrm{nPtFe}$, solutions of $50 \mathrm{mM} \mathrm{H}_{2} \mathrm{PtCl}_{6}$ and $50 \mathrm{mM} \mathrm{FeCl}_{3}$ were mixed (1:1 ratio by volume), then $100 \mathrm{mM} \mathrm{NaBH}_{4}$ was added up to $5 \mathrm{mM}$ while stirring for $20 \mathrm{~min}$. nPtFe were shown to be formed in the reaction mixture after a $24 \mathrm{~h}$ incubation without stirring.

$\mathrm{nAuCePt}$ were obtained by the reduction of metal ions from the appropriate salts with ascorbic acid. The following scheme was used for this NZ synthesis: $5 \mathrm{~mL} 10 \mathrm{mM} \mathrm{HAuCl}$, $5 \mathrm{~mL} 10 \mathrm{mM} \mathrm{Ce}\left(\mathrm{HCO}_{3}\right)_{4}$ and $1 \mathrm{~mL} 100 \mathrm{mM}$ ascorbic acid were mixed. After vigorous stirring for $5 \mathrm{~min}, 5 \mathrm{~mL} 10 \mathrm{mM} \mathrm{H}_{2} \mathrm{PtCl}_{6}$ and $0.1 \mathrm{~mL} 100 \mathrm{mM}$ ascorbic acid were added and the reaction mixture was stirred for $20 \mathrm{~min}$.

All formed NZs were collected by centrifugation, washed with water, and stored as a suspension in water until use at $+4{ }^{\circ} \mathrm{C}$, as described earlier [32,33].

The pseudo-laccase activity was determined in the same way as for natural laccase [30]. Morphological analyses of the samples were performed using scanning electron microscopy (SEM) as described in [32].

\subsection{Apparatus, Measurements, and Statistical Analysis}

The amperometric sensors were evaluated using constant-potential amperometry. The amperometric experiments were carried out in triplicates, using a three-electrode configuration with a graphite rod as a working electrode, a Pt-wire as a counter electrode and an $\mathrm{Ag} / \mathrm{AgCl} / \mathrm{KCl}(3 \mathrm{M})$ as a reference electrode. The analytical characteristics of the sensors were estimated as described earlier [29,31-33].

\subsection{Functionalization and Characterization of the Electrodes}

To construct the NZ-based amperometric sensor, the surface of the graphite electrode (GE) was modified with $5 \mu \mathrm{L}$ of NLac solution $(1 \mathrm{mg} / \mathrm{mL})$ or $5 \mu \mathrm{L}$ of enzyme solution $(12 \mathrm{U} / \mathrm{mL})$. The dried film was covered with $5 \mu \mathrm{L}$ of $0.5 \%$ Nafion solution. After drying at room temperature, the modified GE was washed with $50 \mathrm{mM}$ of acetic buffer, with a pH of 4.5. The electrochemical properties of the functionalized GEs were studied by cyclic voltammetry $(\mathrm{CV})$ and chronoamperometry, and the graphs of the dependences of the amperometric signals in increasing concentrations of AD were compared. The most electroactive $\mathrm{NLac} / \mathrm{GE}$ was chosen and tested as an amperometric sensor for AD determination.

\subsection{Determination of $A D$ in Pharmaceutical Formulation}

$\mathrm{nAuCePt} / \mathrm{GE}$, as the most effective amperometric sensor on $\mathrm{AD}$, was tested on the real sample of the pharmaceutical formulation, "Adrenaline (Epinephrine) solution for injection, ampoule" ("Darnytsia", Kyiv, Ukraine). Each assay, being performed for two dilutions of the sample, was repeated 3 times. The analytical results were statistically processed using the OriginPro 2021 software (OriginLab, One Roundhouse Plaza, Suite 303, Northampton, MA 01060, USA). The manufacturer has declared the following composition of this pharmaceutical product: $1.8 \mathrm{mg} / \mathrm{mL}$ of adrenaline tartrate in water for injections. The tested solution additionally contained sodium metabisulfite (E223) and sodium chloride. 


\section{Conclusions}

In the current research, a number of hybrid metal-based nanoparticles were synthesized by chemical methods and screened for their ability to oxidize AD in solution. The best catalytically active nanoparticles were chosen as artificial laccases. Their structure and electrochemical behavior on electrodes were characterized. The $\mathrm{nAuCePt}$, as the most effective laccase-like nanozyme, was studied in more detail. It was successfully used as a mimetic of laccase in an amperometric sensor for AD analysis in pharmaceuticals. Due to high sensitivity and specificity, the developed nAuCePt-based sensor may be promising in the diagnosis of some diseases, including tumors of the adrenal glands or mental disorders.

Author Contributions: Conceptualization and methodology, O.D., N.S. and G.G.; investigation, N.S. and O.D.; resources, data curation, N.S., G.G. and M.G.; writing - original draft preparation, N.S., O.D. and M.G.; writing—review and editing, N.S., G.G. and M.G.; supervision, M.G.; project administration, M.G.; funding acquisition, M.G. All authors have read and agreed to the published version of the manuscript.

Funding: This research was partially funded by NAS of Ukraine (The program "Smart sensor devices of a new generation based on modern materials and technologies", projects \#13 and \#10/3), by the National Research Foundation of Ukraine (project 2020.02/0100 "Development of new nanozymes as catalytic elements for enzymatic kits and chemo/biosensors"), and by the Ministry of Education and Science of Ukraine (Ukrainian-Lithuanian R\&D, project 0120U103398; 0121U109539; 0121U109543).

Acknowledgments: We would like to thank Nina A. Bisko (M.G. Kholodny Institute of Botany, NAS of Ukraine) for kindly providing the fungal strain used in this study. We are highly appreciative of our colleagues from the Institute of Cell Biology, NAS of Ukraine, namely Maksym D. Lootsik for discussion and critical remarks, and Roman Ya. Serkiz for assistance with SEM experiments.

Conflicts of Interest: The authors declare no conflict of interest.

\section{Abbreviations}

$\begin{array}{ll}\text { ABTS } & \text { 2:2'-Azinobis-(3-ethylbenzthiazoline-6-sulphonate) } \\ \text { AD } & \text { Adrenaline } \\ \text { CV } & \text { Cyclic voltammetry } \\ \text { GCE } & \text { Glassy-carbon electrode } \\ \text { GE } & \text { Graphite electrode } \\ I_{\text {max }} & \text { Maximal current response on tested analyte at substrate saturation } \\ K_{M} \text { app } & \text { Apparent Michaelis-Menten constant } \\ \text { LOD } & \text { Limit of detection } \\ \text { LR } & \text { Linear range } \\ \text { NPs } & \text { Nanoparticles } \\ \text { NZ } & \text { Nanozyme } \\ \text { Me }{ }^{1 / M e}{ }^{2} & \text { Core/shell Nanozyme; where Me }{ }^{1} \text {-core and Me }{ }^{2} \text { - shell } \\ \text { Laccase } & \text { Natural laccase from Trametes gibbosa 1525 } \\ \text { SAT } & \text { Standard addition test } \\ \text { SEM-XRM } & \text { Scanning electron microscopy coupled with X-ray microanalysis } \\ \text { PtE } & \text { Platinum-rod electrode } \\ \text { PPy-PVS } & \text { Polypyrrole-polyvinylsulphonate; } \\ \text { GCE } & \text { Glassy-carbon electrode; } \\ \text { IrOx/SPE } & \text { Iridium-oxide modified screen-printed electrode; } \\ \text { Pt-BMI.PF6 } & \text { PtNPs in 1-butyl-3-methylimidazolium hexafluorophosphate; } \\ \text { CPE } & \text { Carbon-paste electrode } \\ \text { EBNBH } & \text { 2,2-[1,2-ethanediylbis(nitriloethylidyne)]-bis-hydroquinone double-wall } \\ \text { GCE } & \text { carbon-nanotube; } \\ \text { MWCNT/CFE } & \text { Glassy-carbon electrode } \\ \text { AuNPs/PANi/GCE } & \text { Carbon film electrode (CFE) modified with multiwalled carbon-nanotubes } \\ & \text { (MWCNTs) } \\ & \text { Gold nanoparticles / polyaniline Langmuir-modified glassy-carbon } \\ \text { electrode. }\end{array}$




\section{References}

1. Akerman-Sanchez, G.; Rojas-Jimenez, K. Fungi for the bioremediation of pharmaceutical-derived pollutants: A bioengineering approach to water treatment. Environ. Adv. 2021, 4, 100071. [CrossRef]

2. Massima Mouele, E.S.; Tijani, J.O.; Badmus, K.O.; Pereao, O.; Babajide, O.; Zhang, C.; Shao, T.; Sonin, E.; Tarasenko, V.; Fatoba, O.O.; et al. Removal of Pharmaceutical Residues from Water and Wastewater Using Dielectric Barrier Discharge Methods-A Review. Int. J. Environ. Res. Public Health 2021, 18, 1683. [CrossRef]

3. Rebollar-Pérez, G.; Campos-Terán, J.; Ornelas-Soto, N.; Méndez-Albores, A.; Torres, E. Biosensors based on oxidative enzymes for detection of environmental pollutants. Biocatalysis 2016, 1, 118-129. [CrossRef]

4. USGS.gov. Available online: https://toxics.usgs.gov/highlights/PMFs.html (accessed on 18 November 2021).

5. Rana, R.S.; Singh, P.; Kandari, V.; Singh, R.; Dobhal, R.; Gupta, S. A review on characterization and bioremediation of pharmaceutical industries' wastewater: An Indian perspective. Appl. Water Sci. 2017, 7, 1-12. [CrossRef]

6. Taylor, D. The Pharmaceutical Industry and the Future of Drug Development. In Pharmaceuticals in the Environment; Hester, R.E., Harrison, R.M., Eds.; Royal Society of Chemistry: London, UK, 2015; Volume 41, pp. 1-33. Available online: www.rsc.org (accessed on 10 December 2021).

7. McCorry, L.K. Physiology of the Autonomic Nervous System. Am. J. Pharm. Educ. 2007, 71, 78. [CrossRef]

8. Peaston, A.E.; Evsikov, A.V.; Graber, J.H.; Vries, W.N.; Holbrook, A.E.; Solter, D.; Knowles, B.B. Retrotransposons regulate host genes in mouse oocytes and preimplantation embryos. Dev. Cell. 2004, 7, 597-606. [CrossRef] [PubMed]

9. Emamzadeh, F.N.; Surguchov, A. Parkinson's Disease: Biomarkers, Treatment, and Risk Factors. Front. Neurosci. $2018,12,612$. [CrossRef]

10. Zuber, S.M.; Kantorovich, V.; Pacak, K. Hypertension in Pheochromocytoma: Characteristics and Treatment. Endocrinol. Metab. Clin. N. Am. 2011, 40, 295-311. [CrossRef] [PubMed]

11. Thomas, A.; Geyer, H.; Mester, H.J.; Schänzer, W.; Zimmermann, E.; Thevis, M. Quantitative Determination of Adrenaline and Noradrenaline in Urine Using Liquid Chromatography-Tandem Mass Spectrometry. Chromatographia 2006, 64, 587-591. [CrossRef]

12. Bibire, N.; Christopoulos, L.; Apostu, M.; Dorneanu, V. Quantitative determination of adrenaline by visible spectrophotometric method. Rev. Med. Chir. Soc. Med. Nat. Iasi. 2007, 111, 779-782. [PubMed]

13. Liu, C.; Zhang, J.; Zhang, X.; Zhao, L.; Shuang, L. Enantiomeric separation of adrenaline, noradrenaline, and isoprenaline by capillary electrophoresis using streptomycin-modified gold nanoparticles. Mikrochim. Acta 2018, 185, 227. [CrossRef]

14. Menon, S.; Jesny, S.; Sivasankaran, U.; Girish, K.K. Fluorometric Determination of Epinephrine: A Green Approach. Anal. Sci. 2016, 32, 999-1001. [CrossRef]

15. A Kojło, A.; Calatayud, J.M. Spectrophotometric determination of adrenaline with an oxidative column in a FIA assembly. J. Pharm. Biomed. Anal. 1990, 8, 663-666. [CrossRef]

16. Beitollahi, H.; Safaei, M.; Tajik, S. Voltammetric and amperometric sensors for determination of epinephrine: A short review (2013-2017). J. Electrochem. Sci. Eng. 2019, 9, 27-43. [CrossRef]

17. Quan, D.; Shin, W. Amperometric Detection of Catechol and Catecholamines by Immobilized Laccase from DeniLite. Electroanalysis 2004, 16, 1576-1582. [CrossRef]

18. Arslan, F.; Durmus, S.; Colak, O.; Arslan, H. A New Laccase-Based Biosensor for Epinephrine Determination. Gu. J. Sci. 2015, 28, 1-9.

19. Zou, L.; Li, Y.; Cao, S.; Ye, B. Gold nanoparticles/polyaniline Langmuir-Blodgett Film modified glassy carbon electrode as voltammetric sensor for detection of epinephrine and uric acid. Talanta 2013, 117, 333-337. [CrossRef] [PubMed]

20. Salimi, A.; Alizadeh, V.; Compton, R.G. Disposable amperometric sensor for neurotransmitters based on screen-printed electrodes modified with a thin iridium oxide film. Anal. Sci. 2005, 21, 1275-1280. [CrossRef]

21. Brondani, D.; Scheeren, C.W.; Dupont, J.; Vieira, I.C. Biosensor based on platinum nanoparticles dispersed in ionic liquid and laccase for determination of adrenaline. Sens. Actuators B Chem. 2009, 140, 252-259. [CrossRef]

22. Beitollahi, H.; Ardakani, M.M.; Ganjipour, B.; Naeimi, H. Novel 2,2-[1,2-ethanediylbis(nitriloethylidyne)]-bis-hydroquinone double-wall carbon nanotube paste electrode for simultaneous determination of epinephrine, uric acid and folic acid. Biosen. Bioelectron. 2008, 24, 362-368. [CrossRef] [PubMed]

23. Ghica, M.E.; Brett, C.M.A. Simple and efficient epinephrine sensor based on carbon nanotube modified carbon film electrodes. Anal. Let. 2013, 46, 1379-1393. [CrossRef]

24. Ni, J.A.; Ju, H.X.; Chen, H.Y.; Leech, D. Amperometric determination of epinephrine with an osmium complex and Nafion double-layer membrane modied electrode. Anal. Chim. Acta 1999, 378, 151-157. [CrossRef]

25. Agboola, B.O.; Ozoemena, K.I. Efficient electrocatalytic detection of epinephrine at gold electrodes with self-assembled metallooctacarboxyphthalocyanine complexes. Electroanalysis 2008, 20, 1696-1707. [CrossRef]

26. Shankar, S.S.; Shereema, R.M.; Rakhi, R.B. Electrochemical Determination of Adrenaline using MXene/Graphite composite paste electrodes. ACS Appl. Mater. Interfaces 2018, 50, 43343-43351. [CrossRef]

27. Xu, H.; Wang, X.; Chen, R.; Yu, Z. Voltammetric Determination of Epinephrine in the Presence of Uric Acid Based on Aminated Graphene and Ag NPs Hybrid Membrane Modified Electrode. Chem. Res. Chin. Univ. 2014, 30, 205-210. [CrossRef]

28. Turkušić, E.; Redžić, S.; Kahrović, E.; Zahirović, A. Electrochemical Determination of Adrenaline at Ru(III) Schiff Base Complex Modified Carbon Electrodes. Croat. Chem. Acta 2017, 90, 345-352. [CrossRef] 
29. Stasyuk, N.; Gayda, G.; Andriy Zakalskiy, A.; Zakalska, O.; Serkiz, R.; Gonchar, M. Amperometric biosensors based on oxidases and PtRu nanoparticles as artificial peroxidase. Food Chem. 2019, 285, 213-220. [CrossRef]

30. Demkiv, O.M.; Gayda, G.Z.; Broda, D.; Gonchar, M.V. Extracellular laccase from Monilinia fructicola: Isolation, primary characterization and application. Cell Biol. Intern. 2021, 45, 536-548. [CrossRef]

31. Stasyuk, N.; Gayda, G.; Demkiv, O.; Darmohray, L.; Gonchar, M.; Nisnevitch, M. Amperometric biosensors for L-arginine determination based on L-arginine oxidase and peroxidase-like nanozymes. Appl. Sci. 2021, 11, 7024. [CrossRef]

32. Gayda, G.Z.; Demkiv, O.M.; Gurianov, Y.; Serkiz, R.Y.; Klepach, H.M.; Gonchar, M.V.; Nisnevitch, M. “Green” Prussian Blue Analogues as Peroxidase Mimetics for Amperometric Sensing and Biosensing. Biosensors 2021, 11, 193. [CrossRef]

33. Demkiv, O.; Stasyuk, N.; Serkiz, R.; Gayda, G.; Nisnevitch, M.; Gonchar, M. Peroxidase-Like Metal-Based Nanozymes: Synthesis, Catalytic Properties, and Analytical Application. Appl. Sci. 2021, 11, 777. [CrossRef] 